\title{
Crop Considerations for Citrus Lands ${ }^{1}$
}

Stephen H. Futch and Brent A. Sellers ${ }^{2}$

During the period August 2004-January 2006, more than 65,270 acres of citrus have been removed due to citrus canker within Florida, and many growers are asking what alternative crops may be planted on this land. Some growers want rotational crops until they can replant with citrus, whereas others wish to convert the acreage to other agricultural uses.

Before an alternative or rotational crop can be planted, it is necessary to know what herbicides were applied in the citrus grove. This issue must be addressed because some herbicide labels restrict certain crops from being grown for a set amount of time following herbicide application. This is a standard management factor in annual crops where crop rotation is common, but is seldom an issue in perennial crops such as citrus. Preemergence (to the weed) herbicides provide weed control through soil residual activity and can remain active in the soil for many months depending on their breakdown time or the half life of the product (Figs. 1-3).

Postemergence (to the weed) herbicides may or may not have soil residual activity, depending on the chemistry of the herbicide.

Growth of newly planted replacement and rotational crops can be affected by residual

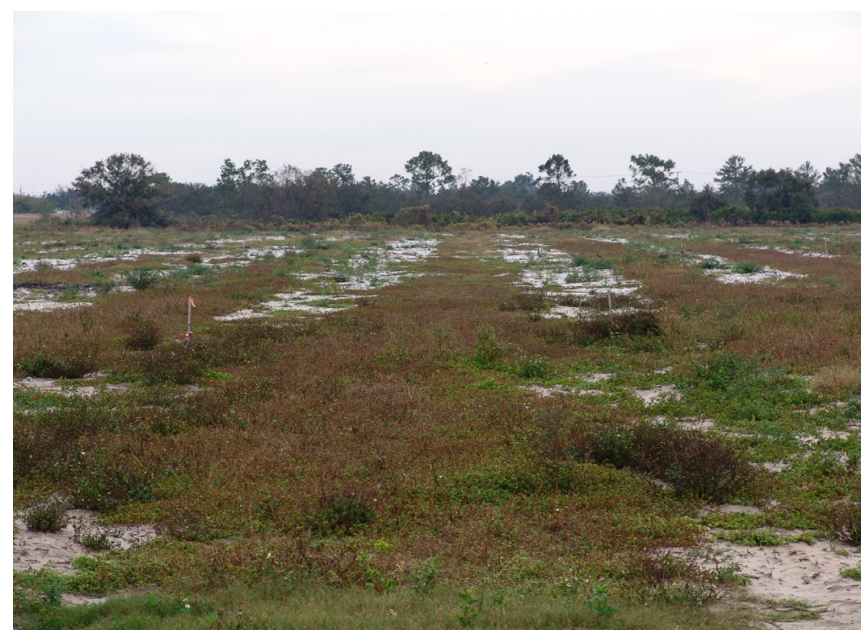

Figure 1. Ridge grove site affected by residual herbicides remaining in the soil. Grove removed approximately 9 months before photo was taken.

herbicide(s) remaining in the soil from previous applications. Crop injury is likely erratic and non-uniform if the land is not entirely uniform in soil type and elevation. Soil variation will lead to different amounts of residual herbicide remaining in the soil. A banding effect may be observed in areas where herbicides were applied repeatedly, particularly turn-around areas. Additionally, the amount of herbicide remaining in the soil depends on the herbicide used, amount applied, frequency of

1. This document is HS1062, one of a series of the Horticultural Sciences Department, Florida Cooperative Extension Service, Institute of Food and Agricultural Sciences, University of Florida. Published March 2006. Visit the EDIS Web site at http://edis.ifas.ufl.edu.

2. S.H. Futch, extension agent IV, Horticultural Sciences Department, Citrus REC, Lake Alfred, FL and B.A. Sellers, assistant professor, Agronomy Department, Range Cattle REC, Ona, FL; Florida Cooperative Extension Service, Institute of Food and Agricultural Sciences, University of Florida, Gainesville, 32611.

The Institute of Food and Agricultural Sciences (IFAS) is an Equal Opportunity Institution authorized to provide research, educational information and other services only to individuals and institutions that function with non-discrimination with respect to race, creed, color, religion, age, disability, sex, sexual orientation, marital status, national origin, political opinions or affiliations. U.S. Department of Agriculture, Cooperative Extension Service, University of Florida, IFAS, Florida A. \& M. University Cooperative Extension Program, and Boards of County Commissioners Cooperating. Larry Arrington, Dean 


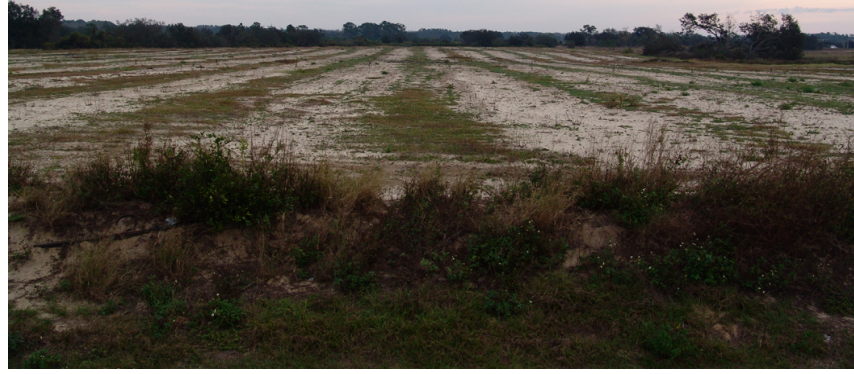

Figure 2. Ridge grove site affected by residual herbicides remaining in the soil 9 months after citrus tree removal.

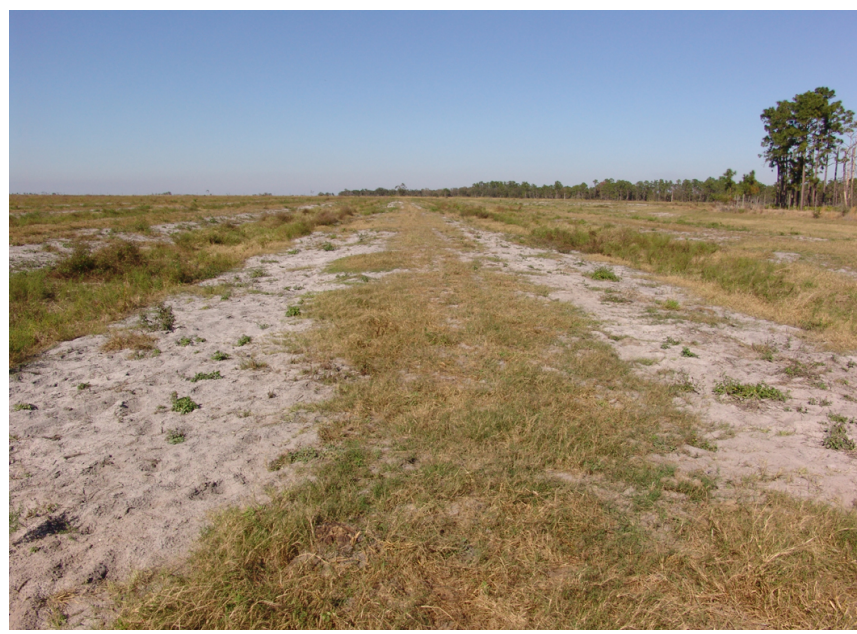

Figure 3. Flatwood grove site affected by residual herbicides remaining in soil 9 months after citrus tree removal.

application, soil type and $\mathrm{pH}$, temperature, rainfall conditions, and the time elapsed since the last herbicide application.

Previous studies have indicated that the break down rate for different herbicides is variable. Not only do products break down at different rates, but the time it takes them to move into soil profile varies with rainfall or irrigation. Historically, weed control in citrus groves has relied upon residual herbicide products that remained active in soil for months, providing broadleaf and grass weed control for at least 90 to 120 days, or longer. Consequently, once a grove is removed, these herbicides may remain active in the soil profile and can impact the growth of alternative or rotational crops.
The amount of herbicide applied is another consideration. The greater the application rate, the greater the possibility that products may still reside at phytotoxic levels. Use of some herbicide products has resulted in improved weed control with repeated soil applications as the herbicide material accumulates in the soil, offering greater weed control with time.

Soil type affects how herbicide products move in the soil profile. Generally speaking, soils with high clay and organic matter content retain herbicides longer, whereas sandier soils with lower organic matter content provide more rapid product movement through soil with time.

Rainfall and irrigation also affect the amount of residual herbicide that remains in the soil profile and the rate of herbicide decay. In general, the higher the rainfall and irrigation the faster the degradation and the lower the chances for the herbicide to remain in the soil profile. Controlled column leaching studies have generally shown how greater rainfall (or irrigation) rates enhance herbicide movement through the soil profile. Products with lower average $\mathrm{K}_{\mathrm{oc}}$ (organic carbon adsorption coefficient) may move deeper into the soil with increased rainfall rates as compared to higher $\mathrm{K}_{\mathrm{oc}}$ products (Table 1 ). The $\mathrm{K}_{\mathrm{oc}}$ describes the relative affinity or attraction of the pesticide or herbicide to soil particles or organic fractions and, therefore, its mobility in soil. Generally, as sand content increases and silt, clay, or organic matter content decreases, the soils will have a greater potential for allowing the leaching movement of herbicides, i.e., sands will have a greater leaching of herbicide than in silt or loam soils.

In some citrus groves, the previously used herbicide product may also restrict planting crops that can be fed to livestock for a period of up to two years. Additionally, planting a rotational crop before the specified plant-back interval specified on the label can result in illegal and punishable violation of pesticide label. If you are in doubt about the herbicide restriction, please refer to your pesticide labels for all the products used over the last 2 to 3 years. 
A few examples of herbicide products which have been used in Florida and have offered outstanding weed control in citrus groves are listed in Table 1. In areas treated with Solicam ${ }^{\circledR}$ (norflurazon), the product label indicates that labeled replacement crops can be planted within from 0 to 24 months after the last application, depending on the crop. However, replacement crops should not be havested, grazed, or fed to livestock for 16 months after the last application. For all other replacement or rotational crops not listed on the label, the rotational interval is 24 months. For these crops, a planting should only be made after a test planting/bioassay of the next intended crop shows no signs of phytotoxicity (whitening in the leaf veins) for 4 months after emergence. This test planting must be done to determine if the soil is free of Solicam ${ }^{\circledR}$ residues. In all situations, the label should be consulted for specific directions.

In the case of $\operatorname{Krovar}^{\circledR}$ (bromacil + diuron) the product label indicates that you should not replant treated areas in any crop within two years after the last application because injury to the subsequent crops may result. The label also cautions that cattle should not be grazed in the treated areas.

The Karmex ${ }^{\circledR}$ (diuron) herbicide label, which does have field crops on its label, prohibits replanting the treated areas in any non labeled crop within two years after the last application. Direx ${ }^{\circledR}$, however, allows for applications of 0.8 to 2.4 quarts of product per acre before emergence of newly sprigged bermudagrass. If emergence has occurred, only 0.4 to 0.8 quarts of product should be applied. Since bermudagrass is on the Dire ${ }^{\circledR}$ label, bermudagrass can be planted into soil previously treated with Direx ${ }^{\circledR}$. However, it would be best to sprig a test strip of bermudagrass the year before to determine whether any injury will occur.

Careful consideration should be given to crops which can be successfully planted into citrus land treated with residual herbicides. Growers are urged to consult the previously used herbicide label(s) and consult the manufacturer's representative to obtain information on crop rotational period and restrictions that may be placed on feeding rotational crops to livestock and about using a bioassay test planting to determine whether herbicide levels remaining in the soil pose a risk to successful crop production.

\section{Bioassay Procedures}

Certain plants can be good indicators of phytoxic level of herbicide residues in the soil. As a bioassay test, the rotational crop can be test planted in strips across the field to determine if injury will occur. In most cases, it is appropriate to conduct the bioassay the year before a rotational crop is to be planted. Although you will not know how much residual herbicide remains in soil, this test will demonstrate whether herbicide residues in soil are low enough to allow for suitable crop production. Rye grass has been successfully used as a bioassay to test for herbicide residues in soil, but in Florida its use should be limited to cooler months of the year.

Whole-field bioassays can be used by planting narrow strips of the rotational crop or a similar species. The test strips should cover the entire length and/or width of the field. This is because herbicide residues are not evenly distributed throughout the field. Dry areas of the field may contain more residues than moist areas. Additionally, areas of spray overlap can result in increased herbicide residues. Plant test strips where herbicide residues are likely to be highly variable such as ends of fields, sprayer turn-around points, or at the ends where sprayer speeds are slightly slower.

An alternative to the whole-field bioassay test strip is to collect soil samples from the field and grow test crops in pots and soil. To do this, sample soil from the field suspected of having herbicide residues 2 to 3 inches deep from several locations using a spade or soil sampler. Be sure to sample soil from both areas where residues are likely to be low (high areas, areas infested with weeds), and areas where residues are likely to be high (turn-around areas, areas without weeds, etc.) while keeping the samples separate. A soil sample of the same soil type and from a non herbicide treated area is also needed for this test. This soil can be obtained from fence-rows or other areas where no residual herbicides were applied. A total of 10 pounds of soil is needed for each type of soil sample. Wet soil should be allowed to partially dry, but for no longer than 2 days. If the 
assay cannot be conducted within a 2 day period, the soil should be stored in a freezer if possible.

Flower pots or half-gallon or larger milk cartons are satisfactory for planting and growing rotational crop species, but use the same kind of container for both suspect (low and high residue) and non-treated soils. Punch holes in the bottom of the containers to allow for water drainage. Fill containers with non herbicide treated soil and the others with the suspect soil and properly identify each container. Plant no more than 10 seeds of the indicator species about an inch deep. Having more than 10 plants in each pot can result in no herbicide response even if the herbicide is present in sufficient quantities to cause injury at the field level. Water the soil as needed. Do not over water nor let the soil dry out completely. Place the containers in a warm area with plenty of sunlight as optimal growing conditions are needed to obtain good results.

\section{Testing for Specific Herbicide Groups}

\section{Triazine, Urea, and Uracil Residues}

When planting test species in the soil as described above, injury symptoms from herbicides such as Princep ${ }^{\circledR}$ (simazine), Direx ${ }^{\circledR} /$ Karmex $^{\circledR}$ (diuron) or Hyvar ${ }^{\circledR}$ (bromacil) should become apparent within 10 to 14 days after emergence. Compare plants in the suspect soil with those growing in the non-treated soil. If residues are present in the suspect soil, the plants will first turn chlorotic (yellow), then the leaf tissue will turn necrotic (brown). Injury symptoms usually occur on older growth first and will develop at the leaf tip and progress downward to the base of the leaf.

\section{Norflurazon Residues}

Norflurazon, the active ingredient in Solicam ${ }^{\circledR}$, inhibits the production of photosynthetic pigments in susceptible plants, causing emerging plants to appear white or without green color (Fig. 4). Lower levels of Solicam ${ }^{\circledR}$ residues may cause test species to become chlorotic. Follow the same procedure as described for detecting triazine residues. Symptoms on test indicator species should be apparent within 2 weeks after emergence. It is essential that you compare plants grown in suspect soil to those grown in non-treated soil.

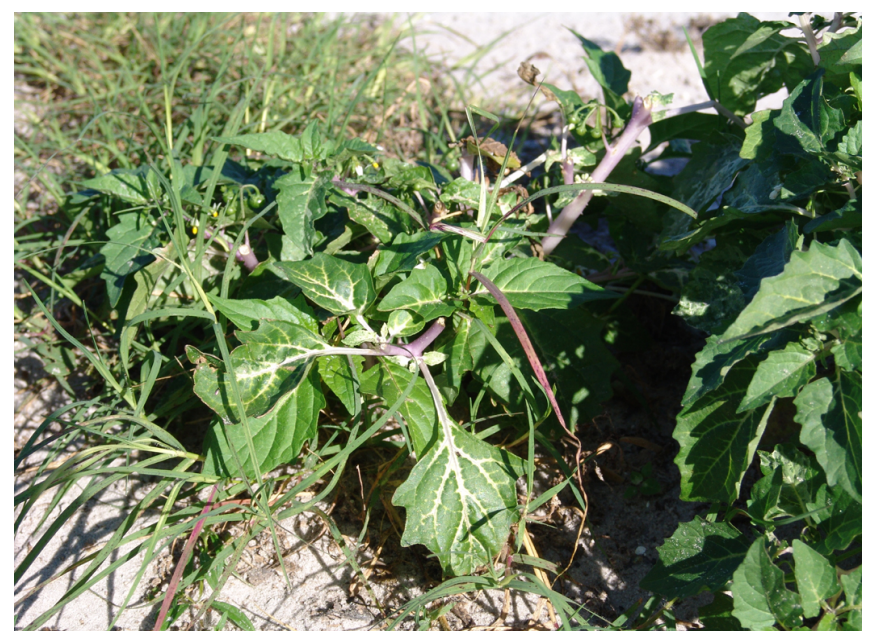

Figure 4. Nightshade growing in previously herbicide treated area showing phytotoxicity (whitening in the leaf veins).

\section{Dinitroaniline Residues}

If soil residues from dinitroaniline (DNA) herbicides, such as Surflan ${ }^{\circledR}$, are suspected, a slightly different assay can be conducted. Instead of planting seeds directly in the soil, soak the seeds of test species in a piece of moist paper towel at room temperature for 2 to 3 days. This allows the seeds to take in water and begin to germinate. Once the seed has germinated, carefully place 5 to 10 seeds into pots containing suspect and non-treated soil. Cover the seeds with about 1 inch of soil and leave them for 10 to 14 days. Water the pots as needed, but do not saturate the soil. At the end of the waiting period, dig up the plants and investigate the roots. DNA-type herbicides inhibit root formation. As a result, plants will appear stunted and the roots will have a stubby appearance. It is extremely important to compare plants grown in suspect soil to those grown in non-treated soil.

\section{Summary}

The removal of a citrus grove naturally enforces a reexamination of alternative land uses. In most cases, growers would like to rotate the land into another agricultural enterprise. Unfortunately, herbicides previously and repeatedly used on the land while citrus was being produced may prevent a grower from planting another crop for at least a year. 
From a regulator perspective, it is necessary to know which herbicides were applied prior to planting any rotational crop, and to consult the labels of those herbicides. Even if the rotational crop of interest is not listed on the herbicide label, it is recommended to perform a bioassay test to determine if there are sufficient residues in the soil to prevent crop establishment and growth to occur. The bioassay procedures outlined above can be used to determine if herbicide residues are too high to plant the crop of choice. It is incorrect to assume that the presence of weeds in a grove implies that all herbicide residues are gone. Crop species are sometimes less tolerant to herbicides than weeds, so it is best to perform the alternative crop bioassay test prior to planting the crop. Even if the crop is able to grow in the suspect soil, label limitations may prevent harvest or feeding of the crop to livestock due to illegal herbicide residues. Therefore, it is necessary to follow all label restrictions even if a rotational crop is tolerant to the residues present in the suspect soil.

Table 1. Frequently used preemergence residual herbcide products for Florida citrus

\begin{tabular}{|c|c|c|c|c|}
\hline $\begin{array}{c}\text { Herbicide } \\
\text { Brand Name }\end{array}$ & $\begin{array}{l}\text { Common } \\
\text { Name }\end{array}$ & $\begin{array}{l}\text { Major Weeds } \\
\text { Controlled }\end{array}$ & $\begin{array}{l}\text { Rotation } \\
\text { Interval }\end{array}$ & $\mathrm{K}_{\mathrm{oc}} \mathrm{mL} / \mathrm{g}$ \\
\hline $\begin{array}{l}\text { Direx }^{\circledR} \\
\text { Karmex }^{\circledR} \\
\text { Diuron }^{\circledR}\end{array}$ & diuron & broadleaf & $12-24$ months & 480 \\
\hline Hyvar $^{(B)}$ & bromacil & grass & 12 months & 32 \\
\hline Krovar $I^{\circledR}$ & bromacil + diuron & broadleaf \& grasses & 24 months & $32 / 480$ \\
\hline Mandate $^{\circledR}$ & thiazopyr & grass & $\begin{array}{c}\text { Not listed, but } \\
\text { suggested } 24 \text { months }\end{array}$ & 250 \\
\hline Princep $^{\circledR}$ & simazine & broadleaf \& grasses & 12 months & 130 \\
\hline Solicam $^{\circledR}$ & norflurazon & grass & $12-24$ months & 700 \\
\hline Surflan $^{\circledR}$ & oryzalin & grass & 12 months & 600 \\
\hline $\mathrm{K}_{\text {oc }}$-- organic & Sorption coeffici & & & \\
\hline
\end{tabular}

